\title{
Qualitative and quantitative phytochemical composition, antimicrobial activity, and brine shrimp cytotoxicity of different solvent extracts of Acanthus polystachyus, Keetia gueinzii, and Rhynchosia elegans
}

James Kiamba Mailu ${ }^{1,2^{*}} \mathbb{D}$, Joseph Mwanzia Nguta ${ }^{1}$, James Mucunu Mbaria ${ }^{1}$ and Mitchel Otieno Okumu ${ }^{1,3}$

\begin{abstract}
Background: The root, root bark, and root tubers of Acanthus polystachyus, Keetia gueinzii, and Rhynchosia elegans are used for managing bacterial and fungal infections among the Luo community of Kisumu East Sub County in Kenya. However, data on the efficacy of these plants against common bacterial and fungal pathogens is not available. The safety of these plants is also not known. This study aimed to investigate the phytochemical composition, antimicrobial properties, and safety of different solvent extracts of the roots, root barks, and root tubers of Acanthus polystachyus, Keetia gueinzii, and Rhynchosia elegans. The broth microdilution method evaluated the antimicrobial activities of the root, root bark, and root tuber extracts (water, acetone, and methanol) of Acanthus polystachyus, Keetia gueinzii, and Rhynchosia elegans. Gram-positive (Bacillus cereus, Staphylococcus aureus), gram-negative (Escherichia coli), and fungal (Candida albicans) microorganisms were used in the evaluation. The safety of the extracts was evaluated in Artemia salina. The phytochemical composition of the extracts was determined using qualitative and quantitative assays.
\end{abstract}

Results: In general, the extracts of Acanthus polystachyus, Keetia gueinzii, and Rhynchosia elegans displayed poor antimicrobial properties relative to conventional antimicrobial agents including Amoxicillin, Gentamicin, and Nystatin. The aqueous extract of Acanthus polystachyus and the aqueous, acetone, and methanol extracts of Keetia gueinzii were safe in Artemia salina but all other extracts were cytotoxic to Artemia salina.

Conclusions: These findings suggest that the use of the roots, root barks, and root tubers of Acanthus polystachyus, Keetia gueinzii, and Rhynchosia elegans is limited by poor antimicrobial efficacy and cytotoxicity.

Keywords: Antimicrobial activity, Medicinal plants, Acanthus polystachyus, Keetia gueinzii, Rhynchosia elegans, Artemia salina

*Correspondence: jkmailu@gmail.com

1 Department of Public Health, Pharmacology, and Toxicology, Faculty of Veterinary Medicine, University of Nairobi, P.O Box 29053-00625,

Nairobi, Kenya

Full list of author information is available at the end of the article

\section{Background}

Antimicrobial Resistance (AMR) is considered to be one of the major public health problems facing mankind [1]. The misuse of antimicrobial agents is a key driver of AMR [1]. Incidences of prolonged illness, the need for expensive medicines, AMR related disability and death highlight the cost of AMR to the global economy [1]. The absence of effective antimicrobial agents 
may jeopardize the success of treatment in important infections which may occur during surgery or cancer [1]. The emergence of drug resistance for clinical isolates of Bacillus cereus, Staphylococcus aureus, Escherichia coli, and Candida albicans have been reported for most of the widely prescribed antibiotics and antifungal drugs such as Amoxicillin, Gentamicin, and Nystatin [2-4]. In the last few years, there has been a global increase in the use of medicinal plants to manage both human and veterinary diseases [5]. This has prompted the World Health Organization (WHO) for the first time to add traditional medicine to the latest revision of the international statistical classification of diseases [6]. Medicinal plants may offer a range of interesting possibilities to fight drug resistance [7-9]. Their diverse pharmacological activities may be exploited for the management of various disease conditions including combating pathogens [10]. Among these plants, Acanthus polystachyus, Keetia gueinzii, and Rhynchosia elegans may hold some promise [11].

Acanthus polystachyus is a shrub of the Acanthaceae family, grows in the wild, and is native to several countries in East Africa including Kenya, Uganda, Tanzania, Burundi, Sudan, and Rwanda [12]. It has pink flowers and soft, hairy leaves [12]. It is traditionally indicated for malaria, scorpion sting, and as an anti-emetic [13, 14]. Studies on the wound healing activity of the leaves have also been reported [12]. Rhynchosia elegans is a perennial climbing herb that belongs to the Fabaceae family and is widely distributed in Eritrea, Ethiopia, Uganda, Kenya, Tanzania, the Democratic Republic of Congo, and Yemen [15]. It is traditionally indicated for malaria, common cold and fever in humans, and blackleg disease, anthrax, and amoebiasis in livestock $[13,16]$. Keetia gueinzii is a shrub of the Rubiaceae family [17]. It has a wide geographical distribution in many African countries including Mozambique, Malawi, Zambia, Cameroon, Sudan, Ethiopia, Rwanda, Burundi, Uganda, Kenya, Tanzania, Central African Republic, and South Africa [17]. It is traditionally indicated for malaria [18]. Acanthus polystachyus (roots), Keetia gueinzii (root barks), and Rhynchosia elegans (root tubers) are used for managing microbial infections in Kenya [11]. There are no pharmacological reports on Rhynchosia elegans and Keetia gueinzii. Moreover, there is a paucity of information on the phytochemical composition, antimicrobial effectiveness, and safety of these plants including Acanthus polystachyus. The present study aimed to fill this gap by determining the phytochemical composition, antimicrobial (bacteria and fungi) activity, and brine shrimp cytotoxicity of the root, root bark, and root tuber extracts of Acanthus polystachyus, Keetia gueinzii, and Rhynchosia elegans prepared using water, acetone, and methanol.

\section{Methods}

\section{Ethical approval}

Ethical approval of the study was obtained from the Biosafety, Animal use and Ethics committee of the Faculty of Veterinary Medicine, University of Nairobi. Ref: FVM BAUEC/2019/210 and the National Commission for Science, Technology \& Innovation (NACOSTI). License No: NACOSTI/P/20/3004.

\section{Plant collection}

The root bark of Keetia gueinzii, roots of Acanthus polystachyus, and root tuber of Rhynchosia elegans were collected in a Sub County in Kisumu with the assistance of traditional medicine practitioners in the study area. The plant samples were identified at the University Herbarium and voucher specimens deposited for future reference; JM2019/264/001 for root bark of Keetia gueinzii, JM2019/284/003 for roots of Acanthus polystachyus, and JM2019/284/002 for root tubers of Rhynchosia elegans.

\section{Preparation of plant material}

Plant parts were washed with running water and allowed to dry. The root bark of Keetia gueinzii was scraped while the whole root of Acanthus polystachyus and root tuber of Rhynchosia elegans were cut into small pieces. The parts were dried in air at room temperature for 4 weeks and ground to a fine powder weighed on an analytical balance, and stored in zip-lock plastic bags awaiting further use.

\section{Extraction \\ Aqueous extract}

The method of Tadesse et al. and Yong et al. were used with modifications $[19,20]$. Briefly, one hundred and sixty-five grams of sample was weighed into a 2-L conical flask and 1-L of distilled water added until there was complete dissolution. The conical flask was placed in a water bath at $90^{\circ} \mathrm{C}$ and incubated for $60 \mathrm{~min}$ with intermittent shaking. The resulting solution was filtered, supernatant collected into 1-L flasks, and freeze-dried using a Buchi Lyovapor freeze drier operating at $0.5 \mathrm{mbar}$ and $-104{ }^{\circ} \mathrm{C}$. The recovered powder was transferred into an air-tight glass container until further use $[19,20]$. The percentage yield of the extract was calculated.

\section{Organic extracts (acetone and methanol)}

The methods of Mostafa et al. and Naz et al. were used with modifications [21, 22]. Briefly, five hundred grams of the powdered plant materials were separately macerated with $100 \%$ acetone and $100 \%$ methanol for $72 \mathrm{~h}$ with intermittent shaking. These were first filtered through cotton wool to remove coarse residues then further filtered through a Whatman No. 1 filter paper and 
centrifuged at $5000 \mathrm{rpm}$ for $10 \mathrm{~min}$. The resulting filtrates were concentrated on a Buchi-R Rota-vapor under reduced pressure at $50{ }^{\circ} \mathrm{C}$. The percentage yield of the extracts was calculated.

\section{Qualitative phytochemical screening}

The methods described by Iqbal et al., Pandey and Jaradat et al. were used to evaluate the presence of alkaloids, phenols, saponins, flavonoids, glycosides, terpenoids, and tannins in the prepared extracts [23-26]. Visual color changes/precipitation was used for evaluation and qualitatively recorded as + to indicate the presence of a metabolite and - to indicate the absence of a metabolite.

\section{Quantitative phytochemical composition Total phenolic content determination}

The phenolic content of the extracts was determined using the methods of Harnafi et al. and Singleton et al. $[27,28]$ with modifications as described by Okumu et al. [29]. The standard which was used to represent phenolics in the extracts was Gallic acid. The standard (Gallic acid; $10 \mathrm{mg}$ ) was dissolved in $100 \mathrm{~mL}$ of methanol. Serial dilutions ranging from 0.25 to 2.0 were pipetted from the prepared standard solution and transferred to $10 \mathrm{~mL}$ volumetric flasks. $2.5 \mathrm{~mL}$ of a 1:10 dilution of Folin reagent and $2.0 \mathrm{~mL}$ of Sodium carbonate $\left(\mathrm{Na}_{2} \mathrm{CO}_{3} ; 7.5 \%\right.$ $\mathrm{w} / \mathrm{v})$ solution was added. Distilled water was added to the mixture until the total volume in the flask was $10 \mathrm{~mL}$. Distilled water + Folin reagent $+\mathrm{Na}_{2} \mathrm{CO}_{3}$ served as the blank. All flasks were kept on a water bath at $45^{\circ} \mathrm{C}$ for $1 / 4$ of an hour. Spectroscopic readings were taken at $765 \mathrm{~nm}$. The readings were used to calibrate a standard curve. The extracts under investigation were weighed $(10 \mathrm{mg})$ and dissolved in $10 \mathrm{~mL}$ of methanol. A pipette was used to transfer one $\mathrm{mL}$ of the extract + methanol mixture to a $10 \mathrm{~mL}$ volumetric flask and the colour was developed in a similar manner to the standard. Spectroscopic readings (in triplicate) of the different extracts were taken at $765 \mathrm{~nm}$. The results were summarized as mean \pm standard deviation (Mean $\pm \mathrm{SD}$ ) and the quantities of phenolics in the test samples were determined by extrapolation from the curve and calculated as milligrams of Gallic acid equivalents per gram of the dry plant material (mg. GAE.g-1). The formula described by Gouveia and coworkers was used [30], i.e.
Catechin. The standard $(10 \mathrm{mg})$ was dissolved in $100 \mathrm{~mL}$ of methanol to make a stock solution. Aliquots of 0.1 to $1.0 \mathrm{~mL}$ were pipetted from the stock solution and transferred to $10 \mathrm{~mL}$ volumetric flasks which contained distilled water ( $4 \mathrm{~mL})$. Sodium Nitrite (NaNO2); $0.3 \mathrm{~mL}(5 \%$ w/v) was added. $10 \% \mathrm{w} / \mathrm{v}$ Aluminum Chloride $\left(\mathrm{AlCl}_{3}\right)$; $0.3 \mathrm{~mL}$ was added after $5 \mathrm{~min} .1 \mathrm{M}$ Sodium hydroxide $(\mathrm{NaOH} ; 2 \mathrm{~mL}$ was added after a further $6 \mathrm{~min}$ and the total volume was made up to the mark using distilled water. Spectroscopic reasings were taken at $510 \mathrm{~nm}$. Distilled water was used to blank the instrument. A calibration curve was prepared from the spectroscopic readings. Extracts were weighed $(10 \mathrm{mg})$ and dissolved in $10 \mathrm{~mL}$ methanol. An aliquot $(1 \mathrm{~mL})$ of each of the extracts was pipetted to $10 \mathrm{~mL}$ volumetric flasks and treated in the same manner as the standard. Spectroscopic readings were taken at $510 \mathrm{~nm}$. Distilled water was used to blank the instrument. All tests were done in triplicate and the results averaged and expressed as mean \pm standard deviation (Mean $\pm \mathrm{SD}$ ). The concentration of flavonoids in the extracts was determined by extrapolation from the curve and calculated as milligrams of Catechin equivalents per gram of the dry plant material (mg. CE. g-1) based on the formula described by Gouveia and co-authors [30] i.e.

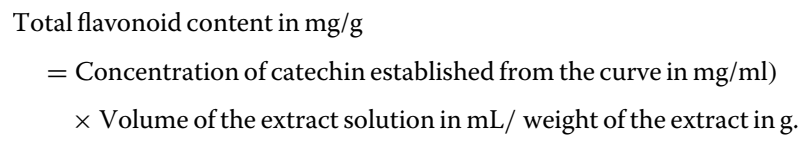

\section{Quantitative determination of tannins}

The method of Amadi et al. was used [32] and Ejikeme et al. [33] were used. Briefly, Sodium tungstate $\left(\mathrm{Na}_{2} \mathrm{WO}_{4}\right) ; 50 \mathrm{~g}$ was dissolved in distilled water $(37 \mathrm{~mL})$ to make the Folin-Denis reagent. Phosphomolybdic acid $\left(\mathrm{H}_{3} \mathrm{PMo1}_{2} \mathrm{O}_{4} 0\right) ; 10 \mathrm{~g}$ and Orthophosphoric acid $\left(\mathrm{H}_{3} \mathrm{PO}_{4}\right)$; $25 \mathrm{~mL}$ were then added. The mixture was refluxed for $2 \mathrm{~h}$, allowed to cool before distilled water was added. Tannic acid $(0.2 \mathrm{~g})$ was dissolved in distilled water, transferred to a $200 \mathrm{~mL}$ volumetric flask, and made up to the mark to make a $1 \mathrm{mg} / \mathrm{mL}$ stock solution. Serial dilutions of the tannic acid solution ranging from $0.2-1.0 \mathrm{mg} / \mathrm{mL}$ were pipetted into $25 \mathrm{~mL}$ volumetric flasks. Folin-Denis reagent $(1.25 \mathrm{~mL})$ was added to each flask followed by $\mathrm{Na}_{2} \mathrm{CO}_{3}$ solution $(2.5 \mathrm{~mL})$. The mixture was made to

Total phenolic content in $\mathrm{mg} / \mathrm{g}=$ Concentration of Gallic acid in $\mathrm{mg} / \mathrm{mL} \times$ Volume of extract solution in mL / weight of the extract in grams $(\mathrm{g})$

\section{Total flavonoid content determination}

The flavonoid content of the prepared extracts was determined according to the method of Atanassova et al. [31] with modifications as described by Okumu et al. [29]. The standard used to represent flavonoids in the extracts was
$100 \mathrm{~mL}$ with distilled water and allowed to stand for $1 / 2$ and hour in a water bath at $25^{\circ} \mathrm{C}$. Absorbance was determined at $700 \mathrm{~nm}$ and the calibration curve was plotted. Each extract was weighed $(0.5 \mathrm{~g})$, transferred to a conical flask, and dissolved in $50 \mathrm{~mL}$ of distilled water. The 
mixture was boiled gently for $60 \mathrm{~min}$ on an electric hot plate and filtered using into a $50 \mathrm{~mL}$ volumetric flask. Folin-Denis reagent $(2.5 \mathrm{~mL})$ and saturated $\mathrm{Na}_{2} \mathrm{CO}_{3}$ solution $(5 \mathrm{~mL})$ was added to $25 \mathrm{~mL}$ of distilled water and $5 \mathrm{~mL}$ of diluted extract. The solution was thoroughly agitated before being allowed to stand for $1 / 2$ an hour in a $25^{\circ} \mathrm{C}$ water bath. Absorbance was read at $700 \mathrm{~nm}$ and the tannic acid content of the extracts was calculated using the formula described by Sheikh and colleagues [34]. i.e.

$$
\begin{aligned}
& \text { Tannic acid }(\mathrm{mg} / 100 \mathrm{~g}) \\
& =\frac{C \times \text { extract volume } \times 100}{\text { Aliquot volume } \times \text { weight of sample }}
\end{aligned}
$$

where $C$ is the concentration of tannic acid read off the graph.

\section{Antimicrobial activity assay \\ Preparation of bacterial and fungal suspension}

The method of Teh et al. was used with minor modifications [35]. Briefly, bacterial stock cultures were subcultured on blood agar and incubated at $37{ }^{\circ} \mathrm{C}$ for $24 \mathrm{~h}$. Fungal stock cultures were sub-cultured in Sabouraud dextrose broth at $35{ }^{\circ} \mathrm{C}$ for $48 \mathrm{~h}$. The test strains were suspended in sterile saline to give a final density of $1.5 \times 10^{6} \mathrm{CFU} / \mathrm{mL}$ of bacteria or $1.5 \times 10^{5}$ spores $/ \mathrm{mL}$ of fungi.

\section{Determination of the minimum inhibitory concentration (MIC) of extracts}

The extracts were tested against bacterial (Escherichia coli ATCC 25922, Staphylococcus aureus ATCC 25923, Bacillus cereus ATCC 11778) and fungal species (Candida albicans ATCC 10231) using broth dilution method as adopted from the method of Teke et al. with slight modifications [36]. About $1.6 \mathrm{~g}$ of the crude extracts were transferred into $4 \mathrm{~mL}$ of pre-sterilized Muller Hinton Broth and Sabouraud dextrose broth for bacteria and fungi respectively contained in a sterilized $10 \mathrm{~mL}$ test tube. Each test tube was clearly labeled and put in a test tube rack. Serial twofold dilutions of plant extracts of 400, 200, 100, 50, 25 and $12.5 \mathrm{mg} / \mathrm{mL}$ concentration were prepared. Using a sterile $1 \mathrm{~mL}$ pipette, $0.1 \mathrm{~mL}$ of bacterial and fungal suspension was dispensed into each of the test tubes. A test tube containing Muller Hinton Broth without extract and $0.1 \mathrm{~mL}$ of the inoculum was used as a negative control. The tubes were incubated at $37^{\circ} \mathrm{C}$ for $24 \mathrm{~h}$ for bacteria and $35{ }^{\circ} \mathrm{C}$ for $48 \mathrm{~h}$ for fungi. All experiments were carried out in triplicate. A two-fold dilution of conventionally used antimicrobials (Amoxicillin, Gentamicin, and Nystatin) were used as positive controls for gram-positive bacteria, gram-negative bacteria, and fungi respectively. Visual turbidity after incubation was used for inference. The minimum inhibitory concentration of the extracts and controls was determined from readings on culture plates and was defined as the lowest concentration of these substances that completely inhibited the growth of the different organisms [37].

\section{Determination of the minimum bactericidal concentration (MBC) and minimum fungicidal concentration (MFC) of extracts}

The method of Mostafa et al. [21] was used to determine the minimum bactericidal concentration $(\mathrm{MBC})$ of the extracts and controls. The method of Wayne et al. [38] was used to determine the minimum fungicidal concentration (MFC) of the extracts and controls. In the determination of the MBC of the extracts, a sterile pipette was used to draw $0.1 \mathrm{~mL}$ suspension from the two lowest concentrations of extracts that exhibited invisible growth in the MIC test tubes. These were then sub-cultured onto sterile Muller Hinton Agar plates, incubated at $37^{\circ} \mathrm{C}$ for $24 \mathrm{~h}$ and microbial growth was examined for each plant extract at different test concentrations. The MBC of the test samples (extracts and controls) was taken as the concentration that did not exhibit any bacterial growth on freshly inoculated agar plates. On the other hand, the MFC was defined as the lowest concentration of test substance (extracts and controls) that prevented visible growth of the fungus.

\section{Artemia salina (Brine shrimp) lethality assay}

The method of Meyer et al. was used [39]. Brine shrimp (Artemia salina) eggs were hatched at room temperature in a shallow rectangular dish containing the marine salt solution prepared by dissolving $38.5 \mathrm{~g}$ of commercial sea salt in $1 \mathrm{~L}$ of distilled water [39]. Ten, 48-h brine shrimp larvae were transferred from the hatching trough to $5 \mathrm{~mL}$ sample vials. Aliquots $(5,50$, and $500 \mu \mathrm{l})$ of $5 \mathrm{mg} / \mathrm{ml}$ stock solutions of the extracts and standard (vincristine sulphate) were pipetted into the sample vials and made up to the mark with marine salt solution to a final concentration of 10,100 , and $1000 \mu \mathrm{g} / \mathrm{mL}$ respectively [39]. Distilled water was used as a control. All experiments were carried out in quintuples and surviving larvae were counted after $24 \mathrm{~h}$. Probit analysis was used to determine the median lethal concentration $\left(\mathrm{LC}_{50}\right)$ of the extracts and the standard cytotoxic drug [40]. Meyer's and Clarkson's toxicity indices were used to classify the acute toxicity of the extracts and standard drug [41, 42]. 


\section{Results}

The ethnobotanical information on the plant species used in this study and the extraction yield is summarized in Table 1 . The percentage yield of the aqueous extracts was $21.20 \%, 17.80 \%$, and $20.20 \%$ respectively for Acanthus polystachyus, Keetia gueinzii, and Rhynchosia elegans. Table 1 . The percentage yield of the acetone extracts was $4.30 \%, 4.90 \%$, and $0.80 \%$ respectively for Acanthus polystachyus, Keetia gueinzii, and Rhynchosia elegans. Table 1 . The percentage yield of the methanol extracts was $20.20 \%, 0.80 \%$, and $5.20 \%$ respectively for Acanthus polystachyus, Keetia gueinzii, and Rhynchosia elegans. Table 1.

The results of the Preliminary phytochemical screening of crude root, root bark, and root tuber extracts of Acanthus polystachyus, Keetia gueinzii, and Rhynchosia elegans are summarized in Table 2. The aqueous root extracts of Acanthus polystachyus contained glycosides, phenols, saponins, and tannins. Table 2. The acetone root extracts of Acanthus polystachyus contained alkaloids, flavonoids, glycosides, and phenols. Table 2. The methanol root extracts of Acanthus polystachyus contained alkaloids, flavonoids, glycosides, phenols, saponins, and terpenoids. Table 2. The aqueous root bark extracts of Keetia gueinzii contained glycosides, phenols, and tannins. Table 2. The acetone root bark extracts of Keetia gueinzii contained alkaloids, flavonoids, glycosides, and phenols. Table 2. The methanol root bark extracts of
Keetia gueinzii contained alkaloids, phenols, saponins, and tannins. Table 2. The aqueous root tuber extracts of Rhynchosia elegans contained phenols, saponins, tannins, and terpenoids. Table 2 . The acetone root tuber extracts of Rhynchosia elegans contained alkaloids, glycosides, flavonoids, phenols, and tannins. Table 2. The methanol root tuber extracts of Rhynchosia elegans contained phenols and saponins. Table 2 . The minimum inhibitory/bactericidal/fungicidal concentrations of the crude root, root bark, and root tuber extracts of Acanthus polystachyus, Keetia gueinzii, and Rychnosia elegans are summarized in Table 3.

The antimicrobial properties of the acetone extracts of Acanthus polystachyus and Keetia gueinzii against grampositive Bacillus cereus were better than the activities of the aqueous and methanol extracts of the plants. Table 3. However, the observed antimicrobial properties were weaker than the standard drug (Amoxicillin). Table 3. Aqueous and acetone extracts of Acanthus polystachyus were ineffective against Staphylococcus aureus at the doses tested. Table 3. The same was true for aqueous and acetone extracts of Rhynchosia elegans. Table 3. The aqueous and acetone extracts of Keetia guenzii exhibited the best antimicrobial properties against S. aureus. Table 3. However, the observed activity was weaker than the standard drug (Amoxicillin). Table 3 All of the prepared extracts of the plants had poor efficacy against E. coli and C. albicans. Table 3 . The brine shrimp cytotoxicity of the

Table 1 Ethnobotanical information on the plant species used in this study and their extraction yield

\begin{tabular}{|c|c|c|c|c|c|c|c|}
\hline \multirow[t]{2}{*}{ Species } & \multirow[t]{2}{*}{ Family } & \multirow[t]{2}{*}{ Local name } & \multirow[t]{2}{*}{ Voucher number } & \multirow[t]{2}{*}{ Part used } & \multicolumn{3}{|c|}{ Extraction yield (\%) } \\
\hline & & & & & Aqueous & Acetone & Methanol \\
\hline Acanthus polystachyus & Acanthaceae & Nyanandi & JM2019/284/003 & Root & 21.20 & 4.30 & 10.10 \\
\hline Keetia gueinzii & Rubiaceae & Atego & JM2019/264/001 & Root bark & 17.80 & 4.90 & 10.90 \\
\hline Rhynchosia elegans & Leguminosae & Jandalusi/Jandarusi & JM2019/284/002 & Root tuber & 20.20 & 0.80 & 5.20 \\
\hline
\end{tabular}

Table 2 Preliminary phytochemical screening of crude root, root bark, and root tuber extracts of Acanthus polystachyus, Keetia gueinzii, and Rhynchosia elegans respectively

\begin{tabular}{|c|c|c|c|c|c|c|c|c|c|c|}
\hline \multirow[t]{2}{*}{ Plant metabolite } & \multirow[t]{2}{*}{ Tests } & \multicolumn{3}{|c|}{$\begin{array}{l}\text { Root extracts of Acanthus } \\
\text { polystachyus }\end{array}$} & \multicolumn{3}{|c|}{$\begin{array}{l}\text { Root bark extracts of Keetia } \\
\text { gueinzii }\end{array}$} & \multicolumn{3}{|c|}{$\begin{array}{l}\text { Root tuber extracts of } \\
\text { Rhynchosia Elegans }\end{array}$} \\
\hline & & Aqueous & Acetone & Methanol & Aqueous & Acetone & Methanol & Aqueous & Acetone & Methanol \\
\hline Alkaloids & Dragendorrf's test & - & + & + & - & - & + & - & + & - \\
\hline Flavonoids & Alkaline reagent test & - & + & + & + & - & - & - & - & - \\
\hline Glycosides & Keller-killiani test & + & + & + & + & + & - & - & + & - \\
\hline Phenols & Ferric chloride test & + & + & + & + & + & + & + & + & + \\
\hline Saponins & Froth test & + & - & + & + & - & + & + & - & + \\
\hline Tannins & Ferric chloride test & + & - & - & + & + & + & + & + & - \\
\hline Terpenoids & Salkowski test & - & - & + & - & - & - & + & - & - \\
\hline
\end{tabular}

+: metabolite present; -: metabolite absent 
Table 3 The minimum inhibitory/bactericidal/fungicidal concentrations of crude root, root bark, and root tubr extracts of Acanthus polystachyus, Keetia gueinzii, and Rychnosia elegans respectively

\begin{tabular}{|c|c|c|c|c|c|c|}
\hline Type of pathogen & Plant extract & $\mathrm{MIC}(\mathrm{mg} / \mathrm{mL})$ & $\mathrm{MBC}(\mathrm{mg} / \mathrm{mL})$ & MFC (mg/mL) & MBC/MIC & MFC/MIC \\
\hline \multirow[t]{12}{*}{ Bacillus cereus (Gram + ve) } & Acanthus polystachyus & & & & & \\
\hline & Aqueous & 25 & 50 & - & 2 & - \\
\hline & Acetone & 12.5 & 12.5 & - & 1 & - \\
\hline & Methanol & 100 & 200 & - & 2 & - \\
\hline & Keetia gueinzii & & & & & \\
\hline & Aqueous & 50 & 100 & - & 2 & - \\
\hline & Acetone & 12.5 & 12.5 & - & 1 & - \\
\hline & Methanol & 25 & 50 & - & 2 & - \\
\hline & Rychnosia elegans & & & & & \\
\hline & Aqueous & ND & ND & - & ND & - \\
\hline & Acetone & * & * & - & * & - \\
\hline & Methanol & ND & ND & - & ND & - \\
\hline \multirow[t]{13}{*}{ Staphylococcus aureus (Gram + ve) } & Acanthus polystachyus & & & & & \\
\hline & Aqueous & ND & ND & - & ND & - \\
\hline & Acetone & ND & ND & - & ND & - \\
\hline & Methanol & 200 & 400 & - & 2 & - \\
\hline & Keetia gueinzii & & & & & \\
\hline & Aqueous & 12.5 & 12.5 & - & 1 & - \\
\hline & Acetone & 12.5 & 12.5 & - & 1 & - \\
\hline & Methanol & 25 & 50 & - & 2 & - \\
\hline & Rychnosia elegans & & & & & - \\
\hline & Aqueous & ND & ND & - & ND & - \\
\hline & Acetone & * & * & - & * & \\
\hline & Methanol & 200 & 400 & - & 2 & \\
\hline & Amoxicillin & 0.00156 & 0.00156 & - & 1 & - \\
\hline \multirow[t]{13}{*}{ Escherichia coli (Gram -ve) } & Acanthus polystachyus & & & & & \\
\hline & Aqueous & ND & ND & - & ND & - \\
\hline & Acetone & ND & ND & - & ND & - \\
\hline & Methanol & 200 & 400 & - & 2 & - \\
\hline & Keetia gueinzii & & & & & \\
\hline & Aqueous & 200 & 400 & - & 2 & - \\
\hline & Acetone & 200 & 400 & - & 2 & - \\
\hline & Methanol & 200 & 400 & - & 2 & - \\
\hline & Rychnosia elegans & & & & & \\
\hline & Aqueous & ND & ND & - & ND & - \\
\hline & Acetone & $*$ & * & - & * & - \\
\hline & Methanol & ND & ND & - & ND & - \\
\hline & Gentamycin & 0.0156 & 0.0156 & - & 1 & - \\
\hline \multirow[t]{10}{*}{ Candida albicans } & Acanthus polystachyus & & & & & \\
\hline & Aqueous & ND & - & ND & - & ND \\
\hline & Acetone & 400 & - & 400 & - & 1 \\
\hline & Methanol & 200 & - & 400 & - & 2 \\
\hline & Keetia gueinzii & & & & & \\
\hline & Aqueous & ND & - & ND & - & ND \\
\hline & Acetone & 200 & - & 400 & - & 2 \\
\hline & Methanol & 100 & - & 200 & - & 2 \\
\hline & Rychnosia elegans & & & & & \\
\hline & Aqueous & ND & - & ND & - & ND \\
\hline
\end{tabular}


Table 3 (continued)

\begin{tabular}{lllllll}
\hline Type of pathogen & Plant extract & MIC $(\mathrm{mg} / \mathrm{mL})$ & $\mathrm{MBC}(\mathrm{mg} / \mathrm{mL})$ & $\mathrm{MFC}(\mathrm{mg} / \mathrm{mL})$ & $\mathrm{MBC} / \mathrm{MIC}$ & $\mathrm{MFC} / \mathrm{MIC}$ \\
\hline Acetone & $*$ & - & $*$ & - & - \\
Methanol & ND & - & ND & - & ND \\
& Nystatin & 0.00156 & - & 0.00156 & - & 1 \\
\hline
\end{tabular}

MIC minimum inhibitory concentration, MBC minimum bactericidal concentration, MFC minimum fungicidal concentration, ND not determined (did not display activity at the tested concentrations)

*Extract not subjected to antimicrobial screening

Table 4 Brine shrimp cytotoxicity of crude root, root bark, and root tuber extracts of Acanthus polystachyus, Keetia gueinzii, and Rhynchosia elegans

\begin{tabular}{|c|c|c|c|c|c|c|c|c|}
\hline \multirow[t]{2}{*}{ Plant species } & \multirow[t]{2}{*}{ Part used } & \multirow[t]{2}{*}{ Solvent used } & \multicolumn{3}{|c|}{ Mortality per test dose } & \multirow[t]{2}{*}{$\mathrm{LC}_{50}(\mu \mathrm{g} / \mathrm{ml})$} & \multicolumn{2}{|l|}{ Toxicity } \\
\hline & & & $10 \mu \mathrm{g} / \mathrm{ml}$ & $100 \mu \mathrm{g} / \mathrm{ml}$ & $1000 \mu \mathrm{g} / \mathrm{ml}$ & & $\begin{array}{l}\text { Meyer's } \\
\text { toxicity } \\
\text { index [41] }\end{array}$ & $\begin{array}{l}\text { Clarkson's } \\
\text { toxicity index } \\
{[44]}\end{array}$ \\
\hline \multirow[t]{3}{*}{ A. polystachyus } & Roots & Acetone & 0 & 1 & 50 & $195.17(109.11-349.08)$ & Toxic & Moderately toxic \\
\hline & & Distilled water & 0 & 0 & 0 & No death & Non-toxic & Non-toxic \\
\hline & & Methanol & 0 & 6 & 49 & $174.26(93.37-325.23)$ & Toxic & Moderately toxic \\
\hline \multirow[t]{3}{*}{ K. gueinzii } & Root bark & Acetone & 0 & 0 & 0 & No death & Non-toxic & Non-toxic \\
\hline & & Distilled water & 0 & 0 & 3 & $\begin{array}{l}148,735,210.7 \\
(2,807,216.20- \\
7,880,462,816)\end{array}$ & Non-toxic & Non-toxic \\
\hline & & Methanol & 0 & 0 & 1 & $\begin{array}{l}1.0 \times 10^{16} \\
\left(2.0 \times 10^{12}-5.1 \times 10^{19}\right)\end{array}$ & Non-toxic & Non-toxic \\
\hline \multirow[t]{3}{*}{ R. elegans } & Root tuber & Acetone & 0 & 2 & 50 & $175.77(98.27-314.39)$ & Toxic & Moderately toxic \\
\hline & & Distilled water & 0 & 0 & 45 & 422.09 (199.52-893.59) & Toxic & Moderately toxic \\
\hline & & Methanol & 0 & 5 & 50 & $168.76(94.35-301.85)$ & Toxic & Moderately toxic \\
\hline $1 \%$ DMSO & - & - & 0 & 0 & 0 & No death & Non-toxic & Non-toxic \\
\hline Vincristine sulphate & - & - & 8 & 31 & 50 & $45.77(19.75-106.06)$ & Toxic & Highly toxic \\
\hline
\end{tabular}

Table 5 Quantitative estimation of phytochemicals responsible for the antimicrobial properties of aqueous, acetone, and methanol extracts of A. polystachyus, K. gueinzii, and R. elegans

\begin{tabular}{llclr}
\hline Plant & Extract & TFC (mg/g CE) & TPC (mg/g GAE) & TC (mg/g TAE) \\
\hline A. polystachyus & Aqueous & 0.32 & 2.14 & 16.61 \\
& Acetone & 15.45 & 8.83 & 8.50 \\
\multirow{2}{*}{ K. gueizii } & Methanol & 2.62 & 2.22 & 7.66 \\
& Aqueous & 16.32 & 3.00 & 80.65 \\
& Acetone & 15.45 & 3.64 & 87.71 \\
R. elegans & Methanol & 18.63 & 3.54 & 85.20 \\
& Aqueous & 2.37 & 2.14 & 9.27 \\
& Acetone & 7.07 & 3.28 & 25.63 \\
\end{tabular}

TFC total flavonoid content, $m g$ milligrams, $g$ grams, GAE gallic acid equivalents, TPC total phenolic content, CE catechin equivalents, TC tannin content, TAE tannic acid equivalents

crude root, root bark, and root tuber extracts of Acanthus polystachyus, Keetia gueinzii, and Rhynchosia elegans is summarized in Table 4. The acetone and methanol extracts of Acanthus polystachyus roots and Rhynchosia elegans root tubers were cytotoxic in brine shrimp with $\mathrm{LC}_{50}$ values less than $100 \mu \mathrm{g} / \mathrm{mL}$. Table 4 . The aqueous 
extracts of the root bark of Acanthus polystachyus, the aqueous, acetone, and methanol extracts of the root bark of Keetia gueinzii, and the aqueous extracts of the root tubers of Rhynchosia elegans were non-cytotoxic to brine shrimp with $\mathrm{LC}_{50}$ values of less than $100 \mu \mathrm{g} / \mathrm{mL}$. Table 4 .

The results of the quantitative analysis of phytochemicals present in the aqueous, acetone, and methanol extracts of the root, root bark, and root tuber extracts of Acanthus polystachyus, Keetia gueinzii, and Rhynchosia elegans are summarized in Table 5. The acetone extract of Acanthus polystachyus had the highest total phenolic content $(8.83 \mathrm{mg} / \mathrm{g}$ GAE) while the methanol extract of Acanthus polystachyus and the aqueous extract of Rhynchosia elegans had the least total phenolic content (2.14 mg/g GAE). Table 5. The acetone extract of Keetia gueinzii had the highest tannin content $(87.71 \mathrm{mg} / \mathrm{g}$ TAE) while the methanol extract of Acanthus polystachyus had the least tannin content $(7.66 \mathrm{mg} / \mathrm{g}$ TAE). Table 5.

\section{Discussion}

Antimicrobial agents have kept disease-causing microbial infections at bay for many decades[10, 43, 44]. However, the tide seems to be changing because microbes continue to develop elaborate mechanisms which confer resistance to the antimicrobial agents which are currently available in the market [45-47]. The development of new drugs to combat the rising threat of antimicrobial resistance is impeded by reduced economic incentives, challenging regulatory requirements, and other factors [48, 49]. New policies and renewed research are therefore urgently required to mitigate the unfolding crisis of antimicrobial resistance. Medicinal plants and their extracts may be suitable alternatives in the quest to solve this crisis. Indeed, literature is rife with reports on the efficacy of medicinal plants against common bacterial and fungal pathogens [50-53]. The practice of traditional herbal medicine in Kenya is deeply entrenched in society. However, scientific data to support the claims emanating from the practice of traditional herbal medicine in the country is scanty. Acanthus polystachyus, Keetia gueinzii, and Rhynchosia elegans are routinely used in Kisumu County to manage a host of diseases including microbial infections [11]. There is a paucity of information on the phytochemical composition, antimicrobial properties, and safety of these plants. This study aimed to determine the phytochemical composition, antimicrobial properties, and safety of different solvent extracts of Acanthus polystachyus, Keetia gueinzii, and Rhynchosia elegans. The yield of the prepared extracts of Acanthus polystachyus, Keetia gueinzii, and Rhynchosia elegans ranged from 0.8\% $\mathrm{w} / \mathrm{w}$ to $21.2 \% \mathrm{w} / \mathrm{w}$. This was higher than the extract yield of Oxalis corniculata, Cinnamomum tamala, Ageratana adenophora, and Artemesia vulgaris which ranged from
$2.38 \% \mathrm{w} / \mathrm{w}$ to $9.35 \% \mathrm{w} / \mathrm{w}$ [54]. The values were similar to the $0.89 \% \mathrm{w} / \mathrm{w}$ to $30.27 \% \mathrm{w} / \mathrm{w}$ yield of water, $50 \%$ ethanol, $70 \%$ ethanol, $95 \%$ ethanol, acetone, and dichloromethane extracts of Blepharis linarifolia, Tinospora bakis, Cyperus rotundus, Maema psudopetalosa, Dicoma tomentosa, and Guiera senegalensis, [55].

The solvents which are used during the extraction period have been reported to exert some influence on the nature and the quantity of secondary metabolites [29, $56,57]$. Therefore, the choice of solvent is a key aspect of achieving the desired pharmacological activity of the plant extracts. In the present study, acetone extracts had the highest total phenolic, total flavonoid, and tannin content. A study on the comparative effects of some extraction solvents on the antimicrobial activity of Eucalyptus camaldulensis revealed that both the type and concentration of the solvent greatly affected the antimicrobial properties of the plant [58]. It was reported that the $30 \%$ acetone extract of Eucalyptus camaldulensis showed the highest inhibition of Acinetobacter baumanni [58]. This trend was also observed when the acetone extracts of Acanthus polystachyus and Keetia gueinzii were tested against the gram-positive Bacillus cereus pathogen.

The minimum inhibitory concentration (MIC) of the extracts against the gram-positive Bacillus cereus ranged from 12.5 to $100 \mathrm{mg} / \mathrm{mL}$. This was higher than the MIC reported on Thai medicinal plant extracts but was lower than the MIC value reported for the acetone extract of Nigella sativa (black curcumin) [55, 59]. The minimum bactericidal concentration (MBC) of the extracts against gram-positive Bacillus cereus ranged from 12.5 to $200 \mathrm{mg} / \mathrm{mL}$. This was higher than the $12.5-25 \mathrm{mg} / \mathrm{mL}$ range reported for the methanol extract of Rosa damascene [60]. The minimum inhibitory (MIC) of the extracts against gram-negative Staphylococcus aureus ranged from 12.5 to $200 \mathrm{mg} / \mathrm{mL}$ while the minimum bactericidal concentration (MBC) ranged from 12.5 to $400 \mathrm{mg} /$ $\mathrm{mL}$. These values were higher than what was reported on 239 traditional Chinese extracts reported by Kim and colleagues who reported MIC values ranging from 0.10 to $12.5 \mathrm{mg} / \mathrm{mL}$ and $\mathrm{MBC}$ values ranging from 0.78 to $25 \mathrm{mg} / \mathrm{mL}$ [61]. The MIC of the extracts against gramnegative $E$. coli ranged from $200 \mathrm{mg} / \mathrm{mL}$ to ineffective. This was higher than the MIC values reported for aqueous and ethanol extracts of the fruit, leaves, and stem of Solanum incanum reported by Sbhatu and Ahraha [62] The MBC of the extracts against gram-negative $E$. coli ranged from 400 to ineffective. These values were comparable to the values reported for extracts prepared from Psidium guajava, Salvia officinalis, Ziziphus sphinachristii, Morus alba, and Olea Europea [63]. The MIC of the extracts against Candida albicans ranged from $100 \mathrm{mg} /$ 
$\mathrm{mL}$ to ineffective. These values were higher than what was reported on essential oils from Nigella sativa, Syzgum animaticum-Thymus vulgaris mixture, and Origanum vulgare which ranged from 0.3 to $48.8 \mathrm{mg} / \mathrm{mL}$ [64]. The solvent extracts studied had MIC or MBC values that were up to 800 fold less effective than the standard drugs. However, it may be of some interest that the extracts of the root bark of Keetia gueinzii generally exhibited a broad spectrum of activity against gram-positive (Bacillus cereus and Staphylococcus aureus), gram-negative (Escherichia coli) bacteria and fungal (Candida albicans) microorganisms. The choice of the solvent appeared to affect the antimicrobial activity of root barks of Keetia gueinzii. Extracts prepared by using highly polar solvents such as water and methanol displayed better antimicrobial activity against Bacillus cereus than the extract prepared using acetone. It is worth noting that phenols, saponins, and tannins were common compounds in both the aqueous and methanol extracts but were absent in the acetone extracts. It could be argued that these compounds may have some role in the antimicrobial activity exhibited by these extracts. Moreover, the presence of alkaloids in the methanol extract of Keetia gueinzii may be the reason for the good antimicrobial activity of this extract against Staphylococcus aureus. Phenols have been shown to significantly reduce biofilm mass formed by $C$. albicans thereby reducing the number of viable cells [65]. This may explain the activity of the aqueous and methanol extracts of Keetia gueinzii against C.albicans.

The total flavonoid content (TFC) of the extracts ranged from 0.32 to $18.63 \mathrm{mg} / \mathrm{g}$ catechin equivalents (CE) while the total phenolic content (TPC) ranged from 2.14 to $8.83 \mathrm{mg} / \mathrm{g}$ gallic acid equivalents (GAE). These values were lower than the TPC and TFC of Alternanthera sesailis, Basella alba, Cassia tora, Digera muricata, ipomoea aquatica, Leucas cephalotes, Portulacea oleracea, and Solanum nigrum [66]. The tannin content of the extracts ranged from 7.66 to $87.7 \mathrm{mg} / \mathrm{g}$ TAE. These values were lower than the aqueous extracts of Cassia asiatica and Musa acuminata [67].

The brine shrimp cytotoxicity of the extracts ranged from 168.76 to $148,735,210.7 \mu \mathrm{g} / \mathrm{mL}$. These values were comparable to those reported by Tlili and colleagues on Hernaria fontanessi, Ziziphus lotus, Plantago ovata, and Thymelaeae hirsuta [68]. Based on the brine shrimp lethality model, acetone and methanol extracts of Acanthus polystachyus and all extracts of Rhynchosia elegans were toxic in the brine shrimp model. The presence of alkaloids and flavonoids in the acetone and methanol extracts of Acanthus polystachyus could be the reason for the observed toxicity. A study on the brine shrimp cytotoxicity of endemic Papuan plants e.g. Piper methysticum and Evodia suaveolens were not only cytotoxic to brine shrimp but were also rich in alkaloids and flavonoids [69]. Further evidence of the brine shrimp cytotoxicity of alkaloids is exemplified in the work of Seremet and colleagues who reported that pyrrolizidine alkaloids isolated from Senecio vernalis, Symphytum officinale, Petasites hybrid, and Tussilago farfara were cytotoxic to brine shrimp [70]. Popovici and colleagues evaluated the antioxidant and Artemia salina cytotoxic activities of Usnea barbata dry extracts in different solvent systems and reported that all extracts (acetone, ethyl acetate, ethanol, methanol, and water) had high cytotoxicity in Artemia salina [71]. This is in agreement with some of the findings of this study particularly in the case of acetone and methanol extracts of Rhynchosia elegans. However, distilled water extracts of Acanthus polystachyus, acetone root bark extracts of Keetia gueinzii, and distilled water and methanol root bark extracts of Keetia gueinzii were relatively safe in Artemia salina.

\section{Conclusions}

The use of the roots, root barks, and root tubers of Acanthus polystachyus, Keetia gueinzii, and Rhynchosia elegans is limited by poor antimicrobial efficacy against Bacillus cereus, Staphylococcus aureus, Escherichia coli, and Candida albicans. Except for the root barks of Keetia gueinzii, the use of all other plants tested is limited by safety concerns.

\section{Abbreviations}

WHO: World Health Organization; FVM: Faculty of Veterinary Medicine; BAUEC: Biosafety animal use and ethics committee; NACOSTI: National Commission for Science, Technology, and Innovation; GAE: Gallic acid equivalents; CE: Catechin equivalents; TAE: Tannic acid equivalents; TPC: Total phenolic content; TFC: Total flavonoid content; TC: Tannin content; UV-VIS: Ultraviolet-visible; CFU: Colony-Forming Unit; MIC: Minimum inhibitory concentration; MBC: Minimum bactericidal concentration; ATCC: American Type Culture Collection; MFC: Minimum Fungicidal Concentration; $\mathrm{LC}_{50}$ : Median lethal concentration in brine shrimp.

\section{Acknowledgements}

The authors are thankful to the Department of Public Health, Pharmacology, and Toxicology for providing research facilities that made this study possible. The authors are also grateful for the support of Mr. Peter Olewe and Mr. Kimeu Musembi for their assistance identification of the medicinal plants collected from the study area.

\section{Authors' contributions}

JKM: Conceptualization, data curation, formal analysis, investigation, methodology, project administration, resources, visualization, writing original draft, and writing review and editing. JMN: Conceptualization, investigation, methodology, supervision, validation, writing review, and editing. JMM: Conceptualization, investigation, methodology, supervision, validation, writing review, and editing. MOO: Formal analysis, investigation, validation, visualization, writing original draft, writing review, and editing. All authors read and approved the final manuscript.

\section{Funding}

This research did not receive any specific grant from any funding agency in the public, commercial or non-profit organizations. 


\section{Availability of data and materials}

The datasets used and/or analyzed during the current study are available from the corresponding author on reasonable request.

\section{Declarations}

\section{Ethics approval and consent to participate}

Not applicable.

\section{Consent for publication}

Not applicable.

\section{Plant authentication}

Samples of the whole plant of Acanthus polystachyus, Keetia gueinzii, and Rhynchosia elegans were collected, transported to the University of Nairobi herbarium where they were authenticated by Mr. Kimeu Musembi. Voucher specimens were deposited for future reference; JM2019/284/003 for roots of Acanthus polystachyus, JM2019/264/001 for root bark of Keetia gueinzii, and JM2019/284/002 for root tubers of Rhynchosia elegans.

\section{Competing interests}

The authors declare that they have no competing interests.

\section{Author details}

'Department of Public Health, Pharmacology, and Toxicology, Faculty of Veterinary Medicine, University of Nairobi, P.O Box 29053-00625, Nairobi, Kenya. ${ }^{2}$ Department of Pharmacy, Kenya Medical Training College, Kisumu Campus Kenya, P.O Box 1594, Kisumu, Kenya. ${ }^{3}$ Department of Pharmacy, Jaramogi Oginga Odinga Teaching and Referral Hospital, P.O Box 849-40100, Kisumu, Kenya.

Received: 4 August 2021 Accepted: 22 September 2021

Published online: 28 September 2021

\section{References}

1. Antimicrobial resistance. http://www.who.int/news-room/fact-sheets/ detail/antimicrobial-resistance. Accessed 31 July 2021

2. Chalmers G, Cormier AC, Nadeau M, Côté G, Reid-Smith RJ, Boerlin $P$ (2017) Determinants of virulence and of resistance to ceftiofur, gentamicin, and spectinomycin in clinical Escherichia coli from broiler chickens in Québec, Canada. Vet Microbiol 203:149-157

3. Abd El Tawab AA, El-Hofy Fl, El-Ekhnawy Kl, El-Shora HE (2019) Detection of some virulence and resistance genes of $S$. aureus and B. cereus isolated from some meat products. Nat Sci 17:85-91. https://doi.org/10.7537/ marsnsj170219.09

4. Freire JCP, de Júnior JKO, de Silva DF, de Sousa JP, Guerra FQS, de Oliveira LE (2017) Antifungal activity of essential oils against Candida albicans strains isolated from users of dental prostheses. Evid Based Complement Altern Med. https://doi.org/10.1155/2017/7158756

5. Ruhsam M, Hollingsworth PM (2018) Authentication of Eleutherococcus and Rhodiola herbal supplement products in the United Kingdom. J Pharm Biomed Anal 149:403-409. https://doi.org/10.1016/j.jpba.2017.11. 025

6. WHO releases new International Classification of Diseases (ICD 11). http:// www.who.int/news-room/detail/18-06-2018-who-releases-new-inter national-classification-of-diseases-(icd-11). Accessed 1 May 2020

7. Subramani R, Narayanasamy M, Feussner KD (2017) Plant-derived antimicrobials to fight against multi-drug-resistant human pathogens. 3 Biotech 7:1-15

8. Khan S, Imran M, Imran M, Pindari N (2017) Antimicrobial activity of various ethanolic plant extracts against pathogenic multi drug resistant Candida spp. Bioinformation 13:67

9. Mulat M, Pandita A, Khan F (2019) Medicinal plant compounds for combating the multi-drug resistant pathogenic bacteria: a review. Curr Pharm Biotechnol 20:183-196

10. Gishen NZ, Taddese S, Zenebe T, Dires K, Tedla A, Mengiste B, Shenkute D, Tesema A, Shiferaw Y, Lulekal E (2020) In vitro antimicrobial activity of six Ethiopian medicinal plants against Staphylococcus aureus, Escherichia coli and Candida albicans. Eur J Integr Med 36:101121. https://doi.org/10. 1016/j.eujim.2020.101121

11. Mailu JK, Nguta JM, Mbaria JM, Okumu MO (2020) Medicinal plants used in managing diseases of the respiratory system among the Luo community: an appraisal of Kisumu East Sub-County, Kenya. Chin Med 15:95. https://doi.org/10.1186/s13020-020-00374-2

12. Demilew W, Adinew GM, Asrade S (2018) Evaluation of the wound healing activity of the crude extract of leaves of Acanthus polystachyus Delile (Acanthaceae). Evid Based Complement Altern Med 2018:1-9. https://doi. org/10.1155/2018/2047896

13. Asnake S, Teklehaymanot T, Hymete A, Erko B, Giday M (2016) Antimalarial medicinal plants used by Gumuz people of mandura woreda, benishangul-gumuz regional state, Ethiopia. Indian J Tradit Knowl 15(4):546-552

14. Teklehaymanot T, Giday M, Medhin G, Mekonnen Y (2007) Knowledge and use of medicinal plants by people around Debre Libanos monastery in Ethiopia. J Ethnopharmacol 111:271-283

15. Rhynchosia elegans in Global Plants on JSTOR. https://plants.jstor.org/ compilation/Rhynchosia.elegans. Accessed 1 May 2020

16. Kidane B, van Andel T, van der Maesen LJG, Asfaw Z (2014) Use and management of traditional medicinal plants by Maale and Ari ethnic communities in southern Ethiopia. J Ethnobiol Ethnomed 10:46. https://doi.org/10.1186/1746-4269-10-46

17. Keetia gueinzii in Global Plants on JSTOR. https://plants.jstor.org/compi lation/Keetia.gueinzii. Accessed 1 May 2020

18. Njoroge GN, Bussmann RW (2006) Diversity and utilization of antimalarial ethnophytotherapeutic remedies among the Kikuyus (Central Kenya). J Ethnobiol Ethnomed 2:1-7. https://doi.org/10.1186/1746-4269-2-8

19. Tadesse E, Engidawork E, Nedi T, Mengistu G (2017) Evaluation of the anti-diarrheal activity of the aqueous stem extract of Lantana camara Linn (Verbenaceae) in mice. BMC Complement Altern Med 17:1-8. https://doi.org/10.1186/s12906-017-1696-1

20. Yong YK, Zakaria ZA, Kadir AA, Somchit MN, Ee Cheng Lian G, Ahmad Z (2013) Chemical constituents and antihistamine activity of Bixa orellana leaf extract. BMC Complement Altern Med 13:32. https://doi.org/ 10.1186/1472-6882-13-32

21. Mostafa AA, Al-Askar AA, Almaary KS, Dawoud TM, Sholkamy EN, Bakri MM (2018) Antimicrobial activity of some plant extracts against bacterial strains causing food poisoning diseases. Saudi J Biol Sci 25:361366. https://doi.org/10.1016/j.sjbs.2017.02.004

22. Naz R, Ayub H, Nawaz S, Islam ZU, Yasmin T, Bano A, Wakeel A, Zia S, Roberts TH (2017) Antimicrobial activity, toxicity and anti-inflammatory potential of methanolic extracts of four ethnomedicinal plant species from Punjab, Pakistan. BMC Complement Altern Med 17:1-13. https:// doi.org/10.1186/s12906-017-1815-z

23. Iqbal E, Salim KA, Lim LBL (2015) Phytochemical screening, total phenolics and antioxidant activities of bark and leaf extracts of Goniothalamus velutinus (Airy Shaw) from Brunei Darussalam. J King Saud Univ Sci 27:224-232. https://doi.org/10.1016/j.jksus.2015.02.003

24. Pandey $S$ (2015) Preliminary phytochemical screening and in vitro antibacterial activity of Bauhinia variegata Linn. against human pathogens. Asian Pac J Trop Dis 5:123-129. https://doi.org/10.1016/S2222-1808(14) 60639-3

25. Jaradat N, Hussen F, Al Ali A, Alniss H, Dweikat M (2015) Phytoconstituents, free radical scavenging potential, total phenols and total flavonoids assessments for Violet Horned Poppy from Jerusalem Mountains. J Mater Environ Sci 6:2958-2966

26. Usman A, Abdulrahman FI, Usman A (2009) Qualitative phytochemical screening and in vitro antimicrobial effects of methanol stem bark extract of Ficus thonningii (Moraceae). AJTCAM 6:289-295. https://doi. org/10.4314/ajtcam.v6i3.57178

27. Harnafi H, Caid HS, el Houda BN, Aziz M, Amrani S (2008) Hypolipemic activity of polyphenol-rich extracts from Ocimum basilicum in Triton WR-1339-induced hyperlipidemic mice. Food Chem 108:205-212

28. Singleton VL, Orthofer R, Lamuela-Raventós RM (1999) Analysis of total phenols and other oxidation substrates and antioxidants by means of folin-ciocalteu reagent. Methods Enymol 1999:152-178

29. Okumu MO, Mbaria JM, Kanja LW, Gakuya DW, Kiama SG, Ochola FO (2016) Phytochemical profile and antioxidant capacity of leaves of Moringa oleifera (lam) extracted using different solvent systems. J Pharmacogn Phytochem 5:302-308 
30. Gouveia S, Castilho PC (2011) Antioxidant potential of Artemisia argentea L'Hér alcoholic extract and its relation with the phenolic composition. Food Res Int 44:1620-1631

31. Atanassova M, Georgieva S, Ivancheva K (2011) Total phenolic and total flavonoid contents, antioxidant capacity and biological contaminants in medicinal herbs. JUCTM 46:81-88

32. Amadi BA, Agomuo EN, Ibegbulem CO (2004) Proximate analysis. Research methods in biochemistry. Supreme Publishers, Owerri, pp 105-115

33. Ejikeme C, Ezeonu CS, Eboatu AN (2014) Determination of physical and phytochemical constituents of some tropical timbers indigenous to nigerdelta area of Nigeria. Eur Sci J 10:247-270

34. Sheikh N, Kumar Y, Misra AK, Pfoze L (2013) Phytochemical screening to validate the ethnobotanical importance of root tubers of Dioscorea species of Meghalaya North East India. J Med Plants 1:62-69

35. Teh CH, Nazni WA, Nurulhusna AH, Norazah A, Lee HL (2017) Determination of antibacterial activity and minimum inhibitory concentration of larval extract of fly via resazurin-based turbidometric assay. BMC Microbiol 17:36. https://doi.org/10.1186/s12866-017-0936-3

36. Teke GN, Elisée KN, Roger KJ (2013) Chemical composition, antimicrobial properties and toxicity evaluation of the essential oil of Cupressus lusitanica Mill leaves from Cameroon. BMC Complement Altern Med 13:130. https://doi.org/10.1186/1472-6882-13-130

37. Balouiri M, Sadiki M, Ibnsouda SK (2016) Methods for in vitro evaluating antimicrobial activity: a review. J Pharm Anal 6:71-79. https://doi.org/10. 1016/j.jpha.2015.11.005

38. Wayne PA (2002) Reference method for broth dilution antifungal susceptibility testing of yeasts, approved standard, CLSI Document M27-A2.

39. Meyer BN, Ferrigni NR, Putnam JE, Jacobsen LB, Nichols DE, McLaughlin $J$ (1982) Brine shrimp: a convenient general bioassay for active plant constituents. Planta Med 45:31-34

40. Finney DJ (1952) Probit analysis: a statistical treatment of the sigmoid response curve. Cambridge University Press, Cambridge

41. Hamidi MR, Jovanova B, Kadifkova Panovska T (2014) Toxicological evaluation of the plant products using Brine Shrimp (Artemia salina L.) model. Maced Pharm Bull 60:9-18. https://doi.org/10.33320/maced.pharm.bull. 2014.60.01.002

42. Clarkson C, Maharaj VJ, Crouch NR, Grace OM, Pillay P, Matsabisa MG, Bhagwandin N, Smith PJ, Folb PI (2004) In vitro antiplasmodial activity of medicinal plants native to or naturalised in South Africa. J Ethnopharmacol 92:177-191

43. Ventola CL (2015) The antibiotic resistance crisis: part 1: causes and threats. Pharm Ther 40:277

44. Spellberg B, Gilbert DN (2014) The future of antibiotics and resistance: a tribute to a career of leadership by John Bartlett. Clin Infect Dis 59(Suppl 2):S71-S75. https://doi.org/10.1093/CID/CIU392

45. Reygaert WC (2018) An overview of the antimicrobial resistance mechanisms of bacteria. AIMS Microbiol 4:482

46. Poole K (2007) Efflux pumps as antimicrobial resistance mechanisms. Ann Med 39:162-176

47. Santajit S, Indrawattana N (2016) Mechanisms of antimicrobial resistance in ESKAPE pathogens. BioMed Res Int. https://doi.org/10.1155/2016/2475067

48. Gould IM, Bal AM (2013) New antibiotic agents in the pipeline and how they can help overcome microbial resistance. Virulence 4:185-191. https://doi.org/10.4161/NIRU.22507

49. Michael CA, Dominey-Howes D, Labbate M (2014) The antimicrobial resistance crisis: causes, consequences, and management. Front Public Health. https://doi.org/10.3389/FPUBH.2014.00145

50. Anand U, Jacobo-Herrera N, Altemimi A, Lakhssassi N (2019) A comprehensive review on medicinal plants as antimicrobial therapeutics: potential avenues of biocompatible drug discovery. Metabolites 9:258

51. Bouyahya A, Bakri Y, Khay EO, Edaoudi F, Talbaoui A, Et-Touys A, Abrini J, Dakka N (2017) Antibacterial, antioxidant and antitumor properties of Moroccan medicinal plants: a review. Asian Pac J Trop Dis 7:57-64

52. Sharma A, del Carmen F-V, Cardoso-Taketa A, Villarreal ML (2017) Antibacterial activities of medicinal plants used in Mexican traditional medicine. J Ethnopharmacol 208:264-329

53. Akhalwaya S, Van Vuuren S, Patel M (2018) An in vitro investigation of indigenous South African medicinal plants used to treat oral infections. J Ethnopharmacol 210:359-371

54. Manandhar S, Luitel S, Dahal RK (2019) In vitro antimicrobial activity of some medicinal plants against human pathogenic bacteria. J Trop Med. https://doi.org/10.1155/2019/1895340
55. Dirar Al, Alsaadi DHM, Wada M, Mohamed MA, Watanabe T, Devkota HP (2019) Effects of extraction solvents on total phenolic and flavonoid contents and biological activities of extracts from Sudanese medicinal plants. S Afr J Bot 120:261-267. https://doi.org/10.1016/J.SAJB.2018.07.003

56. Faroog A (2012) Effect of solvents extraction on total phenolics and antioxidant activity of extracts from flaxseed (Linum usitatissimum L.). Acta Sci Pol Technol Ailment 11(3):293-301

57. Nureye D, Assefa S, Nedi T, Engidawork E (2018) In vivo antimalarial activity of the $80 \%$ methanolic root bark extract and solvent fractions of Gardenia ternifolia Schumach. \& Thonn. (Rubiaceae) against Plasmodium berghei. Evid Based Complement Altern Med. https://doi.org/10.1155/2018/9217835

58. Nasr A, Zhou X, Huang SP, Wang Y, Li X, Zhu GP (2018) Comparative effects of some extraction solvents on the antimicrobial activity of Eucalyptus camaldulensis leaf, bud, capsule and seed crude extracts. Nat Prod Res 33:2560-2565. https://doi.org/10.1080/14786419.2018.1455049

59. Kuncharoen N, Mai Sci CJ, Nanasombat S, Ritcharoon B, Sukcharoen P (2018) Antibacterial activity of thai medicinal plant extracts against oral and gastrointestinal pathogenic bacteria and prebiotic effect on the growth of lactobacillus acidophilus. Chiang Mai J Sci 45(1):33-44

60. Jafari-Sales A, Jafari B, Khaneshpour H, Pashazadeh M (2020) Antibacterial effect of methanolic extract of rosa damascena on standard bacteria Staphylococcus aureus, Bacillus cereus, Escherichia coli and Pseudomonas aeruginosa in vitro. IJNLS 4:40-46

61. Kim G, Gan RY, Zhang D, Farha AK, Habimana O, Mavumengwana V, Li HB, Wang XH, Corke H (2020) Large-scale screening of 239 traditional chinese medicinal plant extracts for their antibacterial activities against multidrug-resistant Staphylococcus aureus and cytotoxic activities. Pathogens 9:185. https://doi.org/10.3390/PATHOGENS9030185

62. Sbhatu DB, Abraha HB (2020) Preliminary antimicrobial profile of Solanum incanum L.: a common medicinal plant. Evid Based Complement Altern Med. https://doi.org/10.1155/2020/3647065

63. Hemeg HA, Moussa IM, Ibrahim S, Dawoud TM, Alhaji JH, Mubarak AS, Kabli SA, Alsubki RA, Tawfik AM, Marouf SA (2020) Antimicrobial effect of different herbal plant extracts against different microbial population. Saudi J Biol Sci 27:3221-3227

64. Najee H, Kamerzan C, Marutescu L, Gheorghe I, Popa M, Grădișteanu G, Lazăr V (2018) Antifungal activity of some medicinal plant extracts against Candida albicans nosocomial isolates. Rom Biotechnol Lett 23:14073. https://doi.org/10.26327/RBL2018.190

65. Guo N, Liu J, Wu X, Bi X, Meng R, Wang X, Xiang H, Deng X, Yu L (2009) Antifungal activity of thymol against clinical isolates of fluconazolesensitive and-resistant Candida albicans. J Med Microbiol 58:1074-1079

66. Aryal S, Baniya MK, Danekhu K, Kunwar P, Gurung R, Koirala N (2019) Total phenolic content, flavonoid content and antioxidant potential of wild vegetables from western Nepal. Plants 8:96. https://doi.org/10.3390/PLANTS8040096

67. Ng ZX, Samsuri SN, Yong PH (2020) The antioxidant index and chemometric analysis of tannin, flavonoid, and total phenolic extracted from medicinal plant foods with the solvents of different polarities. J Food Process Preserv. https://doi.org/10.1111/JFPP.14680

68. Tlili H, Marino A, Ginestra G, Cacciola F, Mondello L, Miceli N, Taviano MF, Najjaa H, Nostro A (2021) Polyphenolic profile, antibacterial activity and brine shrimp toxicity of leaf extracts from six Tunisian spontaneous species. Nat Prod Res 35:1057-1063

69. Lestari MS, Himawan T, Abadi AL, Retnowati R (2015) Toxicity and phytochemistry test of methanol extract of several plants from Papua using the Brine Shrimp Lethality Test (BSLT). J Chem Pharm Res 7:866-872

70. Seremet OC, Olaru OT, Gutu CM, Nitulescu GM, Ilie M, Negres S, Zbarcea CE, Purdel CN, Spandidos DA, Tsatsakis AM (2018) Toxicity of plant extracts containing pyrrolizidine alkaloids using alternative invertebrate models. Mol Med Rep 17:7757-7763

71. Popovici V, Bucur L, Popescu A, Schröder V, Costache T, Rambu D, Cucolea IE, Gîrd CE, Caraiane A, Gherghel D, Vochita G, Badea V (2021) Antioxidant and cytotoxic activities of Usnea barbata (L.) F.H. Wigg. Dry extracts in different solvents. Plants 10:909. https://doi.org/10.3390/PLANTS10050909

\section{Publisher's Note}

Springer Nature remains neutral with regard to jurisdictional claims in published maps and institutional affiliations. 